\title{
PENGARUH PELAYANAN KOPERASI SETJEN DPR-RI TERHADAP KESEJAHTERAAN KARYAWAN PEGAWAI NEGERI SIPIL DPR-RI DI WISMA GRIYA SABHA DPR-RI.
}

\author{
Martina Safitri ${ }^{1}$, dan Amelia ${ }^{2}$ \\ Institut Ilmu Sosial dan Manajemen STIAMI \\ martinasafitry75@gmail.com
}

\begin{tabular}{ll}
\hline ARTIKEL INFO & ABSTRACT \\
\hline
\end{tabular}

Key Word: Quality of Service, Prosperity
In the case of serving a person, the service has standardization to be run by employees in order to create a good influence, and the benchmark used in terms of service is as a reference quality of service to be provided or promised to customers or members. In accordance with the benchmark then the service must be created optimally and prime, which is the excellent service that is good service and even very good done by employees to customers or members. The purpose of this study is to determine the effect of cooperative service of the General Secretariat of the House of Representatives on the welfare of the employees of the DPR RI civil servants in Wisma Griya Sabha DPR RI.

This research method using descriptive method. This research was conducted for 3 (Three) months, ie from May to July 2011. The research was conducted at Wisma Griya Sabha DPR-RI with address Jl. Raya Peak kp. Kebon Cau Kopo, Cisarua Sub-district, Bogor Regency. The population of this research is Employee of Civil Servant of DPR-RI at Wisma Griya Sabha DPR-RI Bogor Regency, which amounts to 30 people.

The result of the research shows that the service of the general staff of the secretariat of DPR-RI can be quite good with the percentage of $43.3 \%$. Welfare of the secretariat general staff of DPR-RI get percentage of $4.60 \%$ which means bigger than the service level of the General Staff Cooperative of DPR-RI Secretariat Based on regression and correlation analysis it can be seen that there is a positive relationship between Service Cooperative Employees Secretariat General DPRI -RI Against Employees' Welfare Employees.

\section{PENDAHULUAN}

Koperasi Indonesia merupakan suatu wadah untuk menyusun perekonomian rakyat yang berdasarkan kekeluargaan dan kegotong-royongan serta merupakan ciri khas dari tata kehidupan bangsa Indonesia, dengan tidak memandang golongan, aliran maupun kepercayaan. Koperasi merupakan jenis atau suatu badan usaha yang beranggotakan orang-orang maupun badan hukum. Dalam kegiatanya koperasi berlandaskan atas dasar prinsip ekonomi rakyat yang berasaskan kekeluargaan. Menurut Undang-Undang 1945 pasal 33 ayat 1 dijelaskan bahwa koperasi merupakan usaha kekeluargaan dengan tujuan mensejahterakan anggotanya, serta koperasi juga dituntut untuk mampu memberdayakan ekonomi rakyat secara nyata, ini terlihat dari apa yang tersirat dan menjadi tujuan pokok koperasi yaitu kesejahteraan anggota pada khususnya dan masyarakat pada umumnya. Dalam hal ini koperasi juga bertujuan untuk memperbaiki kondisi ekonomi para anggotanya menjadi lebih baik dibandingkan sebelum bergabung menjadi anggota koperasi. Hal ini terlihat pula pada Undang-Undang Republik Indonesia No. 25 tahun 1992 pasal 4 Tentang perkoperasian bahwa fungsi dan peranan koperasi yaitu 1) Membangun dan mengembangkan potensi dan kemampuan ekonomi anggota khususnya dan masyarakat pada umumnya, 2) Berperan serta secara aktif dalam upaya mempertinggi kualitas kehidupan manusia dan masyarakat, 3) Memperkokoh perekonomian nasional dengan koperasi sebagai soko gurunya dan 4) Berusaha mewujudkan dan mengembangkan 
perekonomian nasional yang merupakan usaha bersama yang berdasarkan atas azas kekeluargaan dan demokrasi ekonomi.

Peran koperasi sebagai salah satu pelaku ekonomi, sangatlah penting dalam menumbuh kembangkan potensi ekonomi rakyat serta dalam mewujudkan kehidupan demokrasi ekonomi yang mempunyai ciri-ciri demokratis, kebersamaan, kekeluargan, dan keterbukaan.

Keberhasilan suatu koperasi sangat ditentukan oleh kemampuan pengelola dan anggota sebagai pemilik dan pengguna jasa koperasi, dalam aktivitasnya memanfaatkan segala fasilitas atau sumber daya yang ada. Karena dengan adanya pengelolaan yang baik dan berkualitas akan menghasilkan output yang tinggi, yang mendukung tercapainya tujuan koperasi. Dalam hal ini koperasi wajib memberikan bantuan atau mutu pelayanan yang terbaik kepada setiap anggotanya. Melayani dalam hal ini merupakan membantu menyiapkan atau mengurus segala sesuatu yang diperlukan oleh seseorang, sedangkan pelayanan merupakan bagian dari melayani, yakni usaha yang melayani semua kebutuhan orang lain atau dengan kata lain pelayanan merupakan aktivitas / manfaat yang ditawarkan oleh suatu organisasi atau perorangn kepada konsumen (yang dilayani), yang bersifat tidak berwujud dan tidak dapat dimiliki. Sesuai dengan tolak ukur maka pelayanan pun harus diciptakan secara optimal dan prima, yang dimaksud dengan pelayanan prima yakni pelayanan yang baik dan bahkan sangat baik yang dilakukan oleh karyawan terhadap pelanggan atau anggota. Pelayanan prima juga dapat berarti upaya yang maksimum yang mampu diberikan oleh perusahaan atau organisasi jasa pelayanan dalam rangka memenuhi kebutuhan pelanggan untuk mencapai suatu tingkat kepuasan tertentu, serta memberikan pelayanan secara prima kepada para pelanggan dengan tujuan untuk memenangi persaingan. Demikian juga dengan Koperasi Pegawai Setjen DPR-RI yang bergerak dalam bidang koperasi simpan pinjam, pelayanan juga menjadi prioritas dalam pelaksanannnya.

Mengingat pentingnya pelayanan tersebut di atas, maka dalam kesempatan ini penulis tertarik untuk meneliti seberapa besar pelayanan Koperasi setjen DPR-RI terhadap karyawan Pegawai Negeri Sipil wisma griya sabha DPR-RI.

\section{LANDASAN TEORI}

\section{Administrasi}

Pengertian Administrasi dalam bahasa Indonesia ada 2 (dua): Administrasi berasal dari bahasa Belanda, "Administratie" yang merupakan pengertian Administrasi dalam arti sempit, yaitu sebagai kegiatan tata usaha kantor (catat-mencatat, mengetik, menggandakan, dan sebagainya). Kegiatan ini dalam bahasa Inggris disebut: Clerical works (FX.Soedjadi, 1989). Administrasi dalam arti luas, berasal dari bahasa Inggris "Administration" , yaitu proses kerjasama antara dua orang atau lebih berdasarkan rasionalitas tertentu untuk mencapai tujuan bersama yang telah ditentukan (S.P. Siagian, 1994).

\section{Administrasi Negara}

Administrasi Negara atau dikenal juga sebagai Public Administration, yaitu suatu bahasan ilmu sosial yang mempelajari tiga elemen penting kehidupan bernegara yang meliputi lembaga legislatif, yudikatif, dan eksekutif serta hal- hal yang berkaitan dengan publik yang meliputi kebijakan publik, tujuan negara, dan etika yang mengatur penyelenggara negara.

\section{Manajemen}

Menurut Mary Parker ; Follet manajemen adalah suatu seni untuk melaksanakan suatu pekerjaan melalui orang lain. Definisi dari mary ini mengandung perhatian pada kenyataan bahwa para manajer mencapai suatu tujuan organisasi dengan cara mengatur orang-orang lain untuk melaksanakan apa saja yang pelu dalam pekerjaan itu, bukan dengan cara melaksanakan pekerjaan itu oleh dirinya sendiri.

\section{Koperasi}

Menurut Undang-Undang No. 25 tahun 1992 tentang perkoperasian pasal 1 ayat (1) dirumuskan bahwa : "Koperasi adalah badan usaha yang beranggotakan orang seorang atau badan hukum koperasi dengan melandaskan kegiatannya berdasarkan prinsip koperasi sekaligus sebagai gerakan ekonomi rakyat berdasar atas azas kekeluargaan". Pengertian lain tentang koperasi adalah seperti yang dirumuskan International Cooperative Alliance ( ICA ) yang menyebutkan :"Koperasi adalah 
sekumpulan orang-orang yang bekerjasama secara sukarela untuk memenuhi kebutuhan ekonomi, sosial dan budaya, serta aspirasi mereka melalui suatu badan usaha yang terbentuk secara demokratis". Dari pengertian tersebut dapat disimpulkan bahwa koperasi merupakan :

a. Perkumpulan orang-orang yang mempunyai kegiatan yang sama.

b. Badan usaha yang keanggotaannya bersifat sukarela dan terbuka.

c. Secara demokratis, dikelola, dikendalikan dan dimanfaatkan oleh anggota.

d. Mempunyai tujuan untuk meningkatkan anggota, berdasarkan partisipasi dan transaksi masingmasing anggota.

\section{Pola Dasar Manajemen Koperasi}

Agar pengukuran kinerja koperasi dapat dilakukan secara tepat, maka perlu ditetapkan variabel yang dapt digunakan sebagai kriteria pengukurannya. Didalam disiplin ilmu ekonomi tingkat kesejahteraan biasanya diukur berdasarkan tingkat pendapatan dan karena itu didalam tulisan ini digunakan asumsi bahwa tujuan pokok koperasi adlah meningkatkan kesejahteraan / pendapatan anggota. Setiap kegiatan pelayanan koperasi produsen harus diarahkan untuk menghasilkan dampakdampak yang menunjang peningkatan laba usaha anggota koperasi. Setiap kegiatan pelayanan koperasi konsumen harus memberikan dampak terhadap peningkatan pendapatan rill anggota, berarti diarahkan untuk meningkatkan daya beli anggota.

\section{Karakteristik Pelayanan Koperasi}

Manajemen koperasi bertugas melaksanakan program yang telah disetujui oleh rapat anggota. Output dari program itu berbentuk pelayanan-pelayanan kepada anggota yang difokuskan untuk menghasilkan dampak-dampak bagi peningkatan pendapatan anggota. Dengan demikian, pola dasar pengelolaan koperasi meliputi tiga hal, yaitu kepentingan ekonomi anggota, manajemen koperasi dan program pelayanan. Dalam hal ini perlu diperhatikan hal-hal sebagai berikut :

a. Kemampuan dan kapasitas kerja manajemen harus seimbang dengan bobot tugas yang diamanatkan oleh program pelayanan tersebut. Ketidak seimbangan diantar tingkat kemampuan manajemen dengan bobot tugas tersebut dapat mengakibatkan tidak terlaksananya misi koperasi untuk mempromosikan anggota.

b. Keputusan-keputusan operasional yang diambil oleh manajemen koperasi harus sesuai dengan kebutuhan nyata dari rumah tangga anggota. Ketidaksesuaian diantara keduanya dapat memperlemah bahkan menghilangkan motivasi anggota untuk berpartisipasi, baik didalam kedudukannya sebagai pemilik maupun pelanggan koperasi.

c. Program-program pelayanan koperasi harus dirumuskan secara jelas, rasional dan managable dan didukung oleh kapasitas kerja manajemen yang memadai, maka keputusan-keputusan operasional dari manajemen koperasi diharapkan akan terciptanya kecocokan terhadap kebutuhan riil anggota. Akhirnya, pelaksanaan dari program-program koperasi dapat menghasilkan pelayanan-pelayanan yang sesungguhnya dibutuhkan oleh anggota serta menghasilkan dampak-dampak yang meningkatkan kesejahteraan anggota.

\section{Manajemen Anggota}

Manajemen anggota adalah usaha-usaha untuk memposisikan anggota pada kedudukannya sebagai pemilik dan sebagai pelanggan. Sebagai pemilik perusahaan koperasi, anggota memiliki kewajiban-kewajiban sebagai berikut :

a. Turut serta mengambil keputusan-keputusan strategis koperasi, sedangkan keputusan-keputusan operasionalnya dapat saja diarahkan kepada manajemen koperasi.

b. Memodali/membiayai koperasi agar koperasi dapat menjalankan tugas-tugasnya sesuai dengan keputusan rapat anggota.

c. Mengawasi atau mengendalikan jalannya koperasi agar tetap berada pada jalur kepentingan ekonomi anggota sesuai dengan keputusan-keputusan yang telah ditetapkan bersama.

Di dalam kedudukannya sebagai pelanggan, maka anggota koperasi harus menggunakan jasa pelayanan koperasi karena pelayanan koperasi diselenggarakan atas keputusan dan modal anggota sendiri. Jasa pelayanan koperasi diselenggarakan untuk memenuhi kebutuhan anggota. Karena itu (Yuyun Wirasasmita:1996), mengatakan bahwa : 
a. Kebutuhan anggota harus dapat diidentifikasi mengenai jenisnya, jumlahnya, kualitasnya, dan waktunya.

b. Kebutuhan anggota bukan merupakan kebutuhan temporer melainkan kebutuhan utama yang permanen.

c. Kebutuhan anggota harus menjadi dasar setiap penyelenggaraan pelayanan koperasi.

\section{Program Pelayanan Koperasi}

Hanel (1989) menyatakan bahwa koperasi harus menyusun Forderplan (rencana pelayanan) yang jelas dan rasional didalam menjalankan tugas-tugasnya mempromosikan anggota. Pada akhir masa kerja perlu disusun apa yang disebutnya sebagai Forderbilanz (neraca pelayanan). Meskipun bentuk bakunya belum ditemukan, tetapi paling tidak sudah berusaha mengingatkan para pengelola koperasi bahwa kualitas pelayanan terhadap anggota harus menjadi prioritas utama dari manajemen koperasi. Program pelayanan koperasi selayaknya menggambarkan terjadinya perubahan pola produksi dan biaya. Yuyun Wirasasmita (2000) menyatakan bahwa mode of production and cost didalam koperasi terjadi karena pencapaian skala ekonomi, pengurangan biaya transaksi, peningkatan posisi tawar, difinisi informasi dan peningkatan produktivitas. Manajemen koperasi harus menyadari bahwa keputusan individu untuk bergabung ke dalam koperasi merupakan keputusan strategis untuk mengubah keadaan menjadi lebih baik. Keputusan individu bergabung ke dalam koperasi adalah agar anggota memperoleh beberapa manfaat, antara lain (Bratchist, dalam IHCO ; 1994; 484-489)

a. Meningkatkan efisiensi biaya

b. Meningkatkan kualitas produk dan melaksanakan pengembangan produk

c. Kemudahan memperoleh sumber-sumber pembiayaan

d. Pengurangan risiko-risiko usaha

e. Pengembangan fungsi-fungsi baru dan atau meningkatkan fungsi-fungsi yang sudah ada.

\section{Manajemen Keuangan Strategik Koperasi}

Perencanaan keuangan diperlukan untuk mendukung pengembangan usaha dan menghindarkan kesulitan keuangan. Perencanaan keuangan mencakup perencanaan strategis dan perencanaan operasional. Sayangnya anggota koperasi banyak yang kemampuan keuangannya rendah, sehingga sulit mengumpulkan dana yang besar dari anggota. Maka diperlukan kekhususan dalam manajemen keuangan. Manajemen keuangan berkaitan dengan bagaimana menarik dana (financing) dan menggunakannya untuk memperoleh asset (investmen) yang diperlukan dalam operasi perusahaan. Secara normatif tujuan pengambilan keputusan dalam manajemen keuangan adalah memaksimumkan kekayaan perusahaan. Dari kedua keputusan tadi, penarikan dan penman dana, hrus dicari peluang untuk meningkatkan kekayaan perusahaan. Kekayaan perusahaan akan bertambah apabila dana ditanamkan dlam proyek investasi sehingga menghasilkan aliran kas yang nilainya lebih besar dari dana yang ditanamkannya.

a) Strategi Penanaman Dana Dalam Usaha Koperasi

Strategi penanaman dana diartikan sebagai pemilihan peluang untuk menanamkan dana dalam proyek investasi untuk meningkatkan kekayaan perusahaan. Untuk menganalisis peluang investasi dalam usaha koperasi, khusunya segi positif dan negatifnya. Ciri yang spesifik yang hanya dimiliki usaha koperasi adalah bahwa pemilik merupakan pelanggannya. Untuk mengetahui dampak yang ditimbulkannya, mekanisme pasar juga merupakan cara yang paling diandalkan untuk mengalokasikan sumber daya secara efisien dalam suatu sistem perekonomian.

b) Strategi Penarikan Dana

Anggota koperasi akan diuntungkan apabila dia dapat memperoleh barang dan jasa dengan kualitas yang baik dengan harga yang lebih murah daripada apabila dia membelinya dari penjual yang lain. Hal ini dimungkinkan Karena koperasi mempunyai keunggulan kompetitif dalam bidang usahanya dibandingkan dengan perusahaan lain yang berasal dari rendahnya biaya transaksi. Apabila koperasi memerlukan dana untuk memperluas usaha, ada beberapa alternatif yang tersedia. Pertama, apabila perluasan usaha itu dimaksudkan untuk melayani anggota baru, akan diperoleh dana yang berasal dari setoran oleh anggota baru tersebut. Kedua, tambahan dana dapat diperoleh dari hasil operasi yang tidak dibagikan kepada anggota, yang artinya anggota telah memperoleh barang atau pelayanan yang baik dengan harga yang lebih murah. 
mungkin inilah motivasi utama kenapa Ia menjadi anggota koperasi. Jadi pembagian hasil operasi bukan motivasi utama dari keanggotaannya.

c) Keputusan Menarik Dana dan Sumber Penggunaan Modal Koperasi

Keputusan menarik dana adalah memilih alternatif sumber modal yang akan ditarik perusahaan. Pada dasarnya terdapat tiga sumber utama modal bagi suatu perusahaan, yaitu : modal sendiri, modal pinjaman (modal asing), modal penyertaan. Jenis-jenis modal yang berasal dari modal sendiri dipengaruhi oleh badn hokum perusahaannya. Modal pinjaman adalah modal yang berpendapatan tetap, artinya tidak mengenal apakah perusahaan yang menarik modal pinjaman tersebut mendapatkan keuntungan atau bahkn menderita kerugian tetap harus mengembalikan pokok pinjaman dan bunganya sesuai dengan perjanjian yang telah disepakati bersama. Sumber modal koperasi selama ini dihimpun dari sumber internal (penyisihan dari SHU yang diperoleh) berupa cadangan dan sumber eksternal (berasal dari anggota sebagai pemilik, simpanan pokok, simpanan wajib, dan simpanan lainnya yang setara dengan simpanan wajib (hibah), dengan kata lain sumber dana koperasi berasal dari anggota dan non anggota, sedangkan penggunaan dana tersebut digunakan untuk membiayai kegiatan usaha guna melayani anggotanya, melalui investasi dalam bentuk modal kerja.

\section{Dimensi Pelayanan}

Kep. Menpan No. 81/93 menyatakan bahwa pelayanan umum adalah segala bentuk pelayanan yang diberikan oleh pemerintah pusat / daerah, BUMN / BUMD, dalam rangka pemenuhankebutuhan masyarakat, dan atau peraturan perundang-undangna yang berlaku. Tjipjono (1991:61) menyimpulkan bahwa citra kualitas pelayanan yang baik bukanlah berdasarkan sudut pandang/persepsi penyedia jasa, melainkan berdasarkan sudut pandang/persepsi konsumen. Hal ini disebabkan karena konsumenlah yang mengkonsumsi dan yang merasakan serta yang menikmati jasa pelayanan, sehingga merekalah yang seharusnya menentukkan kualitas jasa.

Parasuraman et al $(1994 ; 21)$ menyatakan bahwa terdapat lima dimensi kualitas pelayanan (Servequal), yakni sebagai berikut:

1. Reability (keandalan) merupakan kemampuan yang dapat diandalkan dalam memberikan jasa secara cepat, tepat, akurat dan konsisten sehingga dapat memuaskan anggota sebagai pelanggan.

2. Responsiveness (daya tanggap) adalah keinginan pribadi para staf dan karyawan perusahaan yang secara sadar ingin membantu pelanggan dan memberikan jasa sesegera mungkin sehingga dapat memuaskan pelanggan.

3. Assurance (keterjaminan) mencakup pengetahuan, kemampuan dan keterampilan, kesopanan dan sifat dapat dipercaya yang dimiliki staf dan karyawan sehingga menjamin pelanggan terhindar dari bahaya, risiko, atau keragu-raguan, dan kekecewaan.

4. Emphaty (empati) yang mencakup perhatian individu / pribadi dalam memahami kebutuhan pelanggan, kemudahan melakukan hubungan, komunikasi yang baik dan mudah dipahami.

5. Tangible (keberwujudan fisik) meliputi sarana fisik seperti bangunan dan perlengkapan, penampilan karyawan, sarana komunikasi, dan keberwujudan fisik lainnya yang dapat menjadi perhatian pelanggan.

Sedangkan khusus mengenai pelayanan Koperasi, menurut Arifinal (1990:251),

dimensi/indikator Pelayanan koperasi, meliputi

1. Sesuai standar yang berlaku

2. Mampu memuaskan pihak yang dilayani

3. Sesuai harapan anggota

\section{Kesejahteraan}

Menurut Martoyo (1992:110) program kesejahteraan karyawan adalah merupakan salah satu bentuk pemberian kompensasi berupa penyediaan paket "benefits" dan program-program pelayanan karyawan dengan maksud pokok untuk mempertahankan keberadan karyawan sebagai anggota organisasi dalam jangka panjang. Tujuan dan manfaat program kesejahteraan karyawan adalah untuk membuat karyawan mengabdikan hidupnya pada organisasi dakam jangka panjang.

Menurut PBB : Kesejahteraan sebagai suatu fungsi yang terorganisasi merupakan sekumpulan kegiatan-kegiatan yang ditujukan untuk memberikan kemampuan kepada perorangan, keluarga- 
keluarga, kelompok-kelompok, dan kesatuan-kesatuan masyarakat untuk mengatasi masalah sosial yang diakibatkan oleh kondisi-kondisi yang selalu mengalami perubahan. (1968)

Menurut Malayu S.P. Hasibuan kesejahteraan adalah balas jasa lengkap (materi dan non materi yang diberikan oleh pihak perusahaan berdasarkan kebijaksanaan. Tujuannya untuk mempertahankan dan memperbaiki kondisi fisik dan mental karyawan agar produktifitasnya meningkat. Kesejahteraan dapat dipandang sebagai uang bantuan lebih lanjut kepada karyawan. Terutama pembayarannya kepada mereka yang sakit, uang bantuan untuk tabungan karyawan, pembagian berupa saham, asuransi, perawatan dirumah sakit, dan pensiun. "Pemberian kesejahteraan akan menciptakan ketenangan, semangat kerja, dedikasi, disiplin dan sikap loyal terhadap perusahaan". Dengan tingkat kesejahteraan yang cukup, maka mereka akan lebih tenang dalam melaksanakan tugas-tugasnya. Dengan ketenangan tersebut diharapkan para karyawan akan lebih berdisiplin. Pada dasarnya tujuan kesejahteraan sosial adalah untuk mencapai penyesuaian diri yang baik, menggali sumber-sumber daya, meningkatkan dan mengembangkan taraf hidup yang memuaskan. Adapun tujuan program kesejahteraan pada pegawai menurut Malayu S.P. Hasibuan (2000:187) adalah :

1. Untuk meningkatkan kesetiaan dan ketertarikan pegawai dengan perusahaan.

2. Memberikan ketenangan dan pemenuhan kebutuhan bagi pegawai beserta keluarganya.

3. Memotivasi gairah kerja, disiplin dan produktifitas pegawai.

4. Menurunkan tingkat absensi.

5. Menciptakan lingkungan dan suasana kerja yang baik serta nyaman.

6. Membantu lancarnya pelaksanaan pekerjaan untuk mencapai tujuan.

Sistem kesejahteraan sosial terdiri atas bentuk-bentuk intervensi sosial :

a. Analisis dan perencanaan kebijaksanaan kesejahteraan sosial. Berhubungan dengan pengembangan perundang-undangan serta peraturan-peraturan sosial baik yang mengatur usahausaha pemerintah maupun usaha.

b. Program-program perbaikan penghasilan (income). Berhubungan dengan penyelesaian jaminan dan bantuan finansial ; tunjangan pengangguran, asuransi sosial, pensiun, bantuan korban bencana, bantuan keluarga miskin dsb.

c. Program-program pelayanan sosial. Bentuk pelayanan berupa ; a. terapi, pertolongan, rehabilitasi, b. pelayanan sosialisasi dan pengembangan.

d. Administrasi kesejahteraan sosial. Terutama ditujukan untuk mencapai pelaksanaan pelayanan yang efisien dan efektif sehingga dapat mewujudkan kebijakan-kebijakan sosial yang bermutu tinggi, serta responsif terhadap masalah-masalah sosial.

e. Aksi sosial. Upaya untuk mempengaruhi perbaikan dan perubahan sosial ; dukungan ; seperti dalam berhubungan dengan perburuhan anak, upah minimum, perawatan kesehatan mental, kesehatan lingkungan dan perumahan, pelayanan bagi anak.

\section{Dimensi Kesejahteraan}

Menurut Martoyo (1992:110), dimensi/indikator Kesejahteran pegawai meliputi :

a. Memenuhi kebutuhan pegawai

b. Meningkatkan ekonomi pegawai

c. Membangun potensi pegawai

\section{A. Kerangka Pikir}

\begin{tabular}{|c|c|}
\hline $\begin{array}{l}\text { Pelayanan koperasi } \\
\text { Indikator: } \\
\text { a. Sesuai standar yang berlaku } \\
\text { b. Mampu memuaskan pihak yang dilayani } \\
\text { c. Sesuai harapan anggota } \\
\text { Sumber: Drs. Arifinal (1990:251) }\end{array}$ & $\begin{array}{l}\quad \text { Kesejahteran pegawai } \\
\text { Indikator: } \\
\text { a. Memenuhi kebutuhan pegawai } \\
\text { b. Meningkatkan ekonomi pegawai } \\
\text { c. Membangun potensi pegawai } \\
\text { Sumber : Martoyo (1992:110) }\end{array}$ \\
\hline
\end{tabular}

\section{Hipotesis Penelitian}

Hipotesis dalam penelitian ini adalah terdapat hubungan antara pelayanan koperasi setjen DPRRI terhadap Kesejahteraan Pegawai Negeri Sipil DPR-RI pada Wisma Griya Sabha DPR-RI. 
Ho $: \rho=0$

Ha $: \rho \neq 0$
: tidak ada hubungan (korelasi) antara dua variabel

: terdapat hubungan (korelasi) antara dua variabel

\section{Metode Penelitian}

Metode yang digunakan dalam penelitian ini adalah metode deskriptif. Pengertian metode deskriptif menurut Surahmat $(1994 ; 147)$ yaitu: metode deskriptif adalah metode untuk memecahkan masalah yang aktual dengan jalan mengumpulkan data, menyusun atau mengklasifikasikan masalah, menganalisis, dan menginterpretasikanmya”. Metode kuesioner dengan pendekatan korelasional, yaitu penelitian yang dilakukan untuk memperoleh informasi mengenai kondisi saat ini dengan mengumpulkan informasi mengenai variabel-variabel tertentu dan diarahkan untuk menciptakan kondisi pada saat penelitian dilakukan.

\section{Tempat dan Waktu Penelitian}

Penelitian ini dilakukan selama 3 (Tiga) bulan, yakni mulai bulan Mei sampai dengan Juli 2011. Adapun penelitian ini dilaksanakan di Wisma Griya Sabha DPR-RI dengan alamat Jl. Raya Puncak Kp. Kebon Cau Kopo Kecamatan Cisarua Kabupaten Bogor.

\section{Populasi}

Menurut Sugiyono (2000 : 57), Populasi adalah wilayah generalisasi yang terdiri atas objek atau subjek yang mempunyai kualitas dan karakteristik tertentu yang ditetapkan oleh peneliti untuk dipelajari dan kemudian ditarik kesimpulannya. Populasi target penelitian ini adalah Karyawan Pegawai Negeri Sipil DPR-RI pada Wisma Griya Sabha DPR-RI Kabupaten Bogor, yang berjumlah 30 orang.

\section{Sampel}

Pengambilan sampel dalam penelitian ini dilakukan dengan sensus atau mengambil semua populasi, mengacu kepada pendapat Suharsini Arikunto dan PrasetyoTriawan yang mengatakan apabila populasi $<100$ orang sebaiknya dijadikan sampel semua.

\section{Tehnik Pengumpulan Data}

\section{Jenis dan Macam Data}

Data dan informasi yang diperlukan dalam penelitian ini adalah data primer dan sekunder, baik data yang bersifat kuantitatif maupun data yang bersifat kualitatif.

1. Data primer yaitu data yang diperoleh secara langsung dari obyek penelitian, dalam hal ini yang menjadi responden adalah Karyawan Pegawai Negeri Sipil Sekretariat Jenderal DPR-RI pada Wisma Griya Sabha dan informan adalah pengurus.

2. Data sekunder yaitu data yang diperoleh secara tidak langsung yaitu melalui buku-buku, laporanlaporan serta media lain yang ada hubungannya dengan masalah yang diteliti.

Macam data yang diperlukan dalam penelitian ini adalah :

1. Data yang berhubungan dengan pelaksanaan efektivitas pelayanan terhadap anggota

2. Data tentang keadaan umum tempat penelitian.

\section{Kisi-kisi variabel}

\section{Tabel 1. Fenomena Efektivitas Pelayanan Organisasi}

\begin{tabular}{|l|l|l|l|}
\hline \multicolumn{1}{|c|}{ Variabel } & Sub Variabel & \multicolumn{1}{|c|}{ Dimensi } & \multicolumn{1}{|c|}{ Indikator } \\
\hline $\begin{array}{l}\text { Efektivitas } \\
\text { pelayanan }\end{array}$ & $\begin{array}{l}\text { a. Pencapaian } \\
\text { tujuan }\end{array}$ & $\begin{array}{l}\text { a. pertumbuhan } \\
\text { b. kepuasan }\end{array}$ & $\begin{array}{l}\text { a. perkembangan pendapatan SHU } \\
\text { anggota }\end{array}$ \\
& b. kepuasan & & $\begin{array}{l}\text { b. perkembangan jumlah anggota } \\
\text { c. perkembangan usaha }\end{array}$ \\
& & & $\begin{array}{l}\text { a. SHU bagian dari anggota } \\
\text { b. Pelayanan pada anggota }\end{array}$ \\
& & & c. Program kesejahteraan anggota \\
\hline
\end{tabular}




\section{Sumber Data}

Untuk menunjang penelitian ini, penulis menggunakan teknik pengumpulan data sebagai berikut , Sumber data yang diperlukan untuk memperoleh data dan informasi berasal dari :

1. Informan adalah orang yang mampu menerangkan tentang diri orang lain aatau keadaan tertentu, dalam hal ini adalah pengurus.

2. Responden adalah orang yang dapat menerangkan tentang hal dirinya sendiri, dalam hal ini adalah karyawan pegawai negeri sipil setjen DPR-RI Wisma Griya Sabha.

3. Studi kepustakaan yaitu data yang berupa literatur atau buku-buku yang menunjang pada penelitian ini dan berhubungan dengan masalah yang diteliti.

\section{Tabel 2. Kisi-kisi Instrumen Pelayanan Koperasi}

\begin{tabular}{|l|l|c|c|}
\hline Variabel & \multicolumn{1}{|c|}{ Dimensi } & $\begin{array}{c}\text { Indikator } \\
\text { no pertanyaan }\end{array}$ & Jum \\
\hline Pelayanan & a. Reability (keandalan) & 1.2 .3 & 3 \\
Koperasi & b. Responsiveness(daya tanggap) & 4.5 .6 & 3 \\
& c. Assurance (keterjaminan) & 7 & 1 \\
& d. Emphaty (empati) & 8 & 1 \\
& e. Tangible (keberwujudan fisik) & 9.10 & 2 \\
\hline & & 10 & 10 \\
\hline
\end{tabular}

\section{Cara Pengumpulan Data}

Pengumpulan data dilakukan dengan cara :

1. Studi pustaka yaitu pengumpulan data dengan membaca literatur yang sesuai dengan masalah yang diteliti.

2. Observasi yaitu mengamati secara langsung terhadap objek yang diteliti

3. Kuesioner yaitu menggunakan daftar pentanyaan tertulis yang diberikan pada responden.

Dalam penelitian ini tehnik pengumpulan data dilakukan melalui penyebaran angket yang bersifat tertutup. Menurut Sugiyono (1984 : 74 ) menyebutkan bahwa jawaban setiap item instrumen yang menggunakan skala likert mempunyai gradasi dari sangat positif sampai sangat negatif, dalam skala likert ini penulis menyediakan jawaban skala 5, yaitu : Sangat Baik, baik, cukup baik, kurang baik dan tidak baik

Kemudian Masri Singarimbun (1989 : 80) mengatakan bahwa dalam skala tersebut menurut tingkatan atau secara gradasi masing-masing peneliti dapat menentukan pilihannya diantara : jenjang 3 (1.2.3), jenjang 5 (1.2.3.4.5), dan jenjang 7 (1.2.3.4.5.6.7) .

Berdasarkan pendapat diatas, penulis disini menggunakan jenjang 5 (1.2.3.4.5), kemudian untuk kepentingan analisis secara kuantitatif, maka jawaban dapat diberi skor dengan klasifikasi Sugiyono (1984: 74).

\section{Teknik Analisis Data}

Dalam penelitian ini analisa data menggunakanteknik analisis kualitatif, tetapi untuk mengukur indikator pada setiap variabel penelitiannya maka teknik analisis ini dikembangkan ke dalam teknik kuantitatif, yang prosesnya dapat diuraikan secara garis besar sebagai berikut :

1. Tahap Editing Data

Dalam kegiatan ini dilakukan pengecekan kelengkapan data yang telah terkumpul, yaitu memeriksa isi instrumen pengumpulan data. Apabila ternyata ada kekurangan isi atau halaman, maka perlu dilakukan pengumpulan pengisian angket / kuesioner kepada responden.

2. Tahap Tabulasi Data

Data yang berhasil dikumpulkan dari responden tersebut, kemudian ditabulasi berdasarkan kategori-kategori yang telah ditetapkan sebelumnya sebagai dasar pembuatan perhitungan dengan menggunakan prosentase dan skoring terhadap item-item jawaban pertanyaan.

3. Skoring data

Untuk memudahkan analisis data jawaban responden bersifat data kualitatif, data dirubah menjadi data kuantitatif dengan pemberian skor / nilai sebagai berikut : 
1. Sangat Baik

2. Baik

3. Cukup Baik

4. Kurang Baik

5. Tidak Baik

$$
\begin{aligned}
& \text { nilai }=5 ; \\
& \text { nilai }=4 \\
& \text { nilai }=3 \\
& \text { nilai }=2 \\
& \text { nilai }=1
\end{aligned}
$$

Berangkat dari ketentuan tersebut diatas, maka tingkat kategori jawaban yang diperoleh untuk mengetahui kualitas pelayanan Koperasi Pegawai setjen DPR-RI terhadap Karyawan Pegawai setjen DPR-RI, ditentukan dengan criteria penafsiran sebagai berikut :

$$
\begin{array}{ll}
1,00-1,80 & =\text { Tidak Baik } \\
1,81-2,60 & =\text { Kurang Baik } \\
2,61-3,40 & =\text { Cukup Baik } \\
3,41-4,20 & =\text { Baik } \\
4,20-5,00 & =\text { Sangat Baik }
\end{array}
$$

Kemudian untuk memperoleh angka penafsiran atau interpretasi digunakan rumus perhitungan seperti yang dikemukakan oleh Sanfortd Labovitz dan Robert Hagedorn (1981 : 54)

\section{Analisis angka penafsiran}

$$
\begin{array}{ll}
M & =\sum \frac{\mathrm{fx}}{\mathrm{n}} \\
\mathrm{M} & =\text { angka penafsiran } \\
\sum_{\mathrm{f}} & =\text { penjumlahan } \\
\mathrm{f} & =\text { frekuensi } \\
\mathrm{x} & =\text { nilai } \\
\mathrm{n} & =\text { jumlah seluruh jawaban (jumlah responden) }
\end{array}
$$

\section{Prosedur Pengolahan Data}

Setelah di analisis data yang telah di peroleh di tabulasi dengan melakukan skoring dan editing, serta menganalisis data dengan menggunakan bantuan program computer yaitu dengan menggunakan analisis statistical program for social science (SPSS) dan dilakukan dengan cara deskriptif.

\section{Gambaran Lokasi Penelitian}

Koperasi Pegawai Sekretariat Jenderal DPR-RI didirikan di Jakarta pada tanggal 31 Januari 1985 dan didaftarkan ke Departemen Koperasi dan Pembinaan Pengusaha Kecil Republik Indonesia Kantor Wilayah Propinsi DKI Jakarta dengan No. 2027a/B.H./I. Tanggal 31 Januari 1985.

\section{Struktur Organisasi Koperasi Pegawai Sekretariat Jenderal DPR-RI}

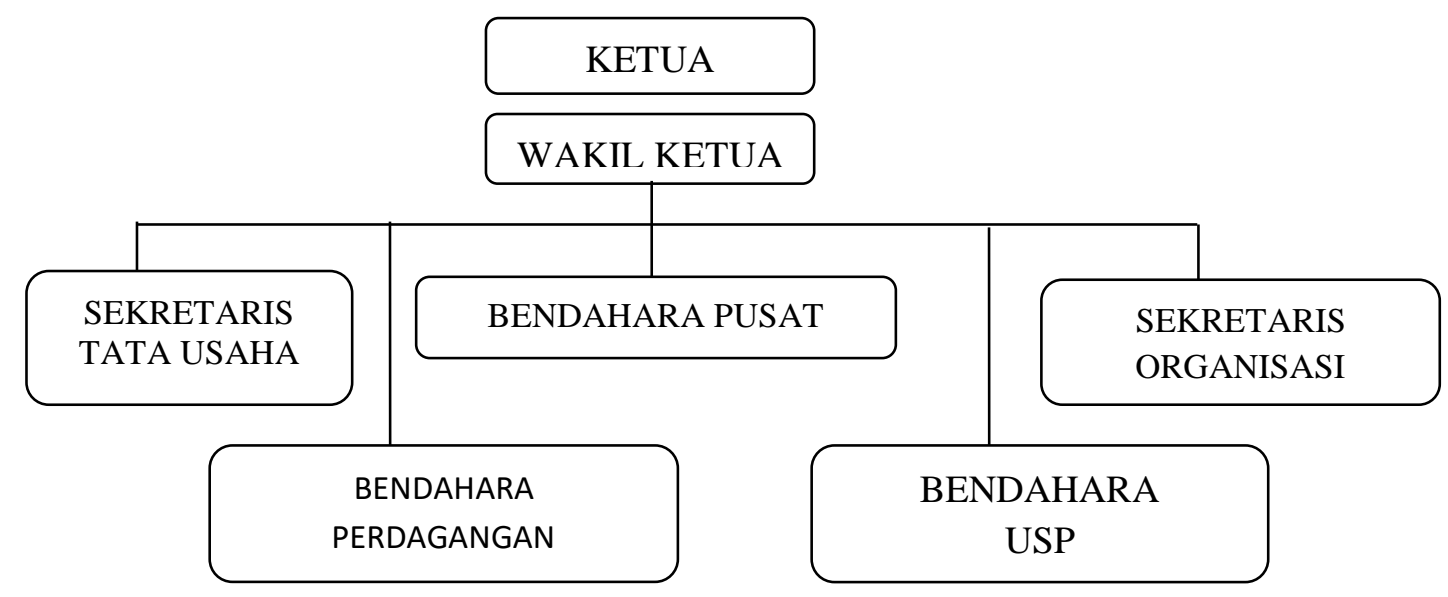

Gambar 1 : Struktur Organisasi

Koperasi Pegawai Sekretariat Jenderal DPR-RI 


\section{Prosedur Sistem Berjalan}

Untuk lebih memahani bagaimana prosedur sistem simpan pinjam pada Koperasi Pegawai Sekretariat Jenderal DPR-RI, berikut ini adalah penjelasannya yang secara garis besar dapat digambarkan dalam lima proses utama, yaitu :

\section{Proses Keanggotaan}

Di dalam proses ini bagi calon anggota yang ingin menjadi anggota koperasi diwajibkan mengisi Surat Pernyataan Menjadi Anggota (SPMA) yang kemudian diserahkan kepada Bagian Unit Simpan Pinjam. Apabil aformulir tersebut disetujui maka Bagian Unit Simpan Pinjam akan memberikan Buku Simpanan Anggota (BSA) yang nantinya akan dipergunakkan untuk simpan pinjam pada koperasi itu. Kemudian oleh Bagian Unit Simpan Pinjam, Surat Pernyataan Menjadi Anggota (SPMA) disimpan dalam arsip SPMA.

2. Proses Simpanan

1) Simpanan pokok sebesar Rp 50.000,- yang dibayarkan ketika pertama kali menjadi anggota koperasi.

2) Simpanan Wajib yang dibayarkan setiap bulan sebesar :
(a) Golongan III
: Rp 100.000,-
(b) Golongan II: Rp 80.000,-
(c) Golongan I : Rp 70.000,-

3) Simpanan sukarela yaitu simpanan yang besarnya tidak ditentukkan melainkan kerelaan dari anggotanya.

\section{Proses Pinjaman}

Pada proses ini, bagi anggota yang ingin meminjam uang terlebih dahulu mengisi Formulir Permohonan Pinjaman (FPP) disertai Buku Simpanan Anggota (BSA) yang diserahkan ke kasir, kemudian kasir menyerahkan Formulir Permohonan Pinjaman (FPP) dan Buku Simpanan Anggota (BSA) tersebut kepada bagian Unit Simpan Pinjam untuk diproses. Jika Formulir Permohonan Pinjaman (FPP) disetujui maka bagian Unit Simpan Pinjam akan menyerahkan Surat Pengakuan Hutang (SPH) untuk pinjaman regular, sedangkan Perjanjian Akad Kredit (PAK) untuk pinjaman insidentil atau Pinjaman Kredit Pemilikan Rumah (KPR) yang dibuat rangkap dua (yang pertama untuk kasir yang kedua untuk arsip). Setelah itu kasir akan menyerahkan uang pinjamam sebesar pinjaman yang diajukan anggota yang dicatat dalam Kartu Pengawasan Pinjaman (KPP) dan diserahkan ke bagian Unit Simpan Pinjam, kemudian Kartu Pengawasan Pinjaman (KPP) tersebut disimpan dalam arsip KPP. Kasir akan memberikan salinan Surat Pengakuan Hilang (SPH) atau Perjanjian Akad Kredit (PAK) sebagai bukti pinjaman yang diserahkan kepada Anggota.

4. Proses Pembayaran

Pada proses ini, pembayaran pinjama dipotong dari Gaji/Uang Pelayanan Sidang (UPS) / Bantuan Pelayanan Kerja Dewan (BPKD) anggota yang melakukan pinjaman oleh bagian Unit Simpan Pinjam selama 10 bulan sampai 10 tahun tergantung pinjaman dengan melihat arsip KPP dan arsip SPH/PAK.

1) Pinjaman Reguler sebesar 1 juta - 5 juta selama 10 bulan - 12 bulan.

2) Pinjaman Insidentil sebesar 5 juta -20 juta selama 24 bulan -60 bulan.

3) Pinjaman KPR maksimal 150 juta selama 5 tahun - 10 tahun.

Yang kemudian dicatat oleh bagian Unit Simpan Pinjam pada Kartu Pengawasan Pinjaman (KPP) yang disimpan dalam arsip KPP.

5. Proses Pembuatan Laporan

Pada setiap akhir bulan bagian Unit Simpan Pinjam (USP) menyusun laporan mengenai simpan pinjam dengan melihat arsip SPMA, arsip simpanan dan arsip KPP dan setiap akhir tahun laporan tersebut akan dirangkum yang kemudian diserahkan kepada Ketua Koperasi Simpan Pinjam yang berupa neraca untuk dibahas dalam rapat tahunan anggota koperasi yang diselenggarakan setiap tahun sekali.

6. Kegiatan Koperasi

Kegiatan koperasi terbagi menjadi dua kegiatan besar yaitu kegiatan yang berhubungan dengan anggota dan non anggota, kegiatan yang berhubungan dengan murni anggota adalah pada unit simpan pinjam dan perdagangan kredit, kegiatan yang berhubungan dengan non anggota 
adalah took koperasi (mini market unit) dan pujasera. Secara umum masing-masing kegiatan tersebut adalah sebagai berikut:

a. Unit Simpan Pinjam (USP)

Mengacu pada peraturan pemerintah No. 9 tahun 1995 tentang pelaksanaan kegiatan Usaha Simpan Pinjam (USP), dan keputusan Menteri Koperasi dan Pembinaan Pengusaha Kecil Republik Indonesia No. 226/KEP/M/V/1996 dan No. 227/KEP/M/V/1996 tentang petunjuk pelaksanaan kegiatan Usaha Simpan Pinjam oleh Koperasi. Kegiatan Usaha Simpan Pinjam (USP) antara lain :

1) Menghimpun simpanan koperasi dan tabungan koperasi anggota.

2) Memberikan pinjaman kepada anggota

3) Dalam hal terdapat kelebihan dana, dana ditempatkan dalam bentuk giro, saham dan obligasi

b. Toko Koperasi (Mini Market Koperasi)

Merupakan suatu kegiatan usaha dalam pemenuhan kebutuhan sehari-hari anggota dan non anggota baik secara tunai maupun kredit. Kegiatan ini dalam bentuk pendirian took koperasi atau dikenal dengan toserba dilingkungan kantor secretariat jenderal DPR-RI.

c. Pujasera

Merupakan suatu kegiatan usaha dalam pelayanan kepada anggota dan non anggota. Ini merupakan sub unit usaha baru yang mengaplikasikan konsep kemitraan terpadu antara koperasi, Sekretariat Jenderal DPR-RI, Investor, dan Pengusaha Kecil.

d. Rekanan dan Perawatan

Merupakan suatu kegiatan usaha untuk memperoleh keuntungan bagi koperasi yang berasal dari institusi dibidang perawatan dan pengadaan barang -barang dilingkungan Sekretariat Jenderal DPR-RI.

\section{Keadaan Karyawan Pegawai Negeri Sipil Sekretariat Jenderal DPR-RI}

Jumlah keseluruhan pegawai negeri sipil setjen DPR-RI yang ada pada Wisma Griya Sabha yaitu 30 orang. Sedangkan komposisi pegawai negeri sipil setjen DPR-RI pada Wisma Griya Sabha adalah sebagai berikut :

a) Berdasarkan Pangkat dan Golongan

Tabel 3. Berdasarkan Pangkat dan Golongan

\begin{tabular}{|c|c|c|}
\hline No & Golongan & Jumlah \\
\hline 1 & III & 7 \\
\hline 2 & II & 10 \\
\hline 3 & I & 7 \\
\hline 4 & Non Nip & 6 \\
\hline
\end{tabular}

Sumber : Tabel 3 diambil dari struktur organisasi Pegawai Negeri Sipil setjen DPR-RI pada Wima Griya Sabha.

b) Berdasarkan Tingkat Pendidikan

Tabel 4. Berdasarkan Tingkat Pendidikan

\begin{tabular}{|c|c|c|}
\hline No & Pendidikan & Jumlah \\
\hline 1 & S2 & 1 \\
\hline 2 & S1 & 10 \\
\hline 3 & D3 & 10 \\
\hline 4 & SMA/SMK & 9 \\
\hline
\end{tabular}

Sumber : Struktur organisasi Pegawai Negeri Sipil

Setjen DPR-RI pada Wima Griya Sabha. 
c) Berdasarkan Jenis Kelamin

Tabel 5. Berdasarkan Jenis Kelamin

\begin{tabular}{|c|c|c|}
\hline Perempuan & Laki-Laki & Jumlah \\
\hline 10 & 20 & 30 \\
\hline
\end{tabular}

Sumber: Struktur organisasi Pegawai Negeri Sipil Setjen DPR-RI pada Wima Griya Sabha

\section{Deskripsi Analisis dan Interpretasi Data}

\section{Deskripsi dan hasil penelitian}

Untuk memberikan gambaran umum mengenai penyebaran atau distribusi data. Perhitungan untuk memperoleh angka pelayanan koperasi $\mathrm{X}$ dan Kesejahteraan pegawai Y. Penelitian ini melibatkan responden yang berjumlah 30 orang yaitu Pegawai Negeri Sipil Sekretariat Jenderal DPRRI pada Wisma Griya Sabha. Karena penulis meneliti hubungan antara pelayanan koperasi terhadap kesejahteraan pegawai untuk itu penulis membutuhkan data pelayanan koperasi melalui hasil sebaran angket yang kemudian dilakukan penghitungan. Data yang telah di dapat kemudian di hitung dengan menggunakan bantuan komputer yaitu dengan menggunakan SPSS 12 yang hasilnya

\section{Tabel 6. Descriptive statistics} Statistics

\begin{tabular}{|l|r|r|}
\hline & Pelayanan & Kesejahteraan \\
\hline $\mathrm{N} \quad$ Valid & 30 & 30 \\
$\quad$ Missing & 0 & 0 \\
Mean & 4.1700 & 3.8867 \\
Median & 4.2000 & 3.9000 \\
Mode & 4.10 & 4.20 \\
Std. Deviation & .37522 & .33501 \\
Variance & .141 & .112 \\
Minimum & 2.90 & 3.20 \\
Maximum & 4.80 & 4.60 \\
\hline
\end{tabular}

\section{Pelayanan Koperasi}

Dari hasil perhitungan dengan menggunakan komputer yang memakai SPSS (Analisis statistical program for social science) nilai mean atau nilai rata-rata pelayanan koperasi adalah 4,17 nilai median atau nilai tengah yang di dapat adalah 4,20 dan nilai mode atau nilai yang sering muncul adalah 4,10 sedangkan nilai standar deviasinya adalah 0,37 sedangkan nilai minimum atau nilai terkecil adalah 2,90 dan nilai maksimum atau nilai yang paling besar adalah 4,80 . 
Tabel 7. Pelayanan

\begin{tabular}{|cc|c|c|c|c|}
\hline & & Frequency & Percent & Valid Percent & $\begin{array}{c}\text { Cumulative } \\
\text { Percent }\end{array}$ \\
\hline Valid & 2.9 & 1 & 3.3 & 3.3 & 3.3 \\
& 3.3 & 1 & 3.3 & 3.3 & 6.7 \\
& 3.6 & 1 & 3.3 & 3.3 & 10.0 \\
3.8 & 1 & 3.3 & 3.3 & 13.3 \\
4.1 & 9 & 30.0 & 30.0 & 43.3 \\
4.2 & 3 & 10.0 & 10.0 & 53.3 \\
& 4.3 & 4 & 13.3 & 13.3 & 66.7 \\
4.4 & 7 & 23.3 & 23.3 & 90.0 \\
4.6 & 2 & 6.7 & 6.7 & 96.7 \\
4.8 & 1 & 3.3 & 3.3 & 100.0 \\
& Total & 30 & 100.0 & 100.0 & \\
\hline
\end{tabular}

Dari tabel pelayanan koperasi dapat dilihat bahwa nilai 4,1 / 4,17 valid yang berarti nilai kumulativ persennya 43,3 menunjukkan tingkat pelayanan koperasi pegawai setjen DPR-RI sudah cukup tinggi.

Tabel 8. Kesejahteraan

\begin{tabular}{|cc|c|c|c|c|}
\hline & & Frequency & Percent & Valid Percent & $\begin{array}{c}\text { Cumulative } \\
\text { Percent }\end{array}$ \\
\hline Valid & 3.2 & 2 & 6.7 & 6.7 & 6.7 \\
& 3.4 & 1 & 3.3 & 3.3 & 10.0 \\
& 3.6 & 6 & 20.0 & 20.0 & 30.0 \\
3.8 & 6 & 20.0 & 20.0 & 50.0 \\
4 & 6 & 20.0 & 20.0 & 70.0 \\
& 4.2 & 7 & 23.3 & 23.3 & 93.3 \\
4.4 & 1 & 3.3 & 3.3 & 96.7 \\
4.6 & 1 & 3.3 & 3.3 & 100.0 \\
& Total & 30 & 100.0 & 100.0 & \\
\hline
\end{tabular}

Dari hasil penghitungan terhadap data yang telah di dapat tentang kesejahteraan karyawan pegawai setjen DPR-RI didapat hasil jumlah nilai mean atau nilai rata-ratanya adalah 3,88 dan nilai median atau nilai yang tengah adalah 3,90 dan nilai mode atau nilai yang sering muncul adalah 4,20 sedangkan standar deviasinya adalah 0,33 kemudian nilai minimum atau nilai yang paling kecil adalah 3,20 dan nilai maksimum atau nilai yang paling besar adalah 4,60.

\section{Data perolehan skor pelayanan koperasi (variabel $x$ )}

Data pelayanan koperasi pegawai diperoleh melalui pengisian angket dengan lima alternativ jawaban, yaitu : Sangat Baik, Baik, Cukup Baik, Kurang Baik, Tidak Baik.

Setelah dilakukan perhitungan data yang dikumpulkan menghasilkan gambaran data seperti dibawah ini : 
Tabel 9. Gambaran Persepsi Pelayanan

\begin{tabular}{|c|l|l|l|}
\hline No & Pelayanan Koperasi & Skor & $\%$ \\
\hline 1 & $\begin{array}{l}\text { Apakah prosedur pelayanan simpan pinjam yang dilakukan oleh } \\
\text { koperasi kepada anggota Mudah dilaksanakan, Mudah dipahami, dan } \\
\text { Tidak berbelit-belit? }\end{array}$ & 137 & 91,33 \\
\hline 2 & $\begin{array}{l}\text { Apakah sistem pembayaran yang berlaku di pujasera koperasi, sudah } \\
\text { tepat dan jelas untuk anggota ? }\end{array}$ & 128 & 85,33 \\
\hline 3 & $\begin{array}{l}\text { Bagaimana ketepatan dan kepastian waktu yang diberikan koperasi, } \\
\text { ketika memberikan pelayanan dalam proses pencairan dana simpan } \\
\text { pinjam, apakah sesuai dengan kurun waktu yang telah ditentukan ? }\end{array}$ & 126 & 84,00 \\
\hline 4 & $\begin{array}{l}\text { Apakah setiap karyawan di Unit koperasi sudah menjalankan tugas } \\
\text { dan melayani anggota dengan maksimal? }\end{array}$ & 123 & 82,00 \\
\hline 5 & $\begin{array}{l}\text { Apakah selama ini koperasi merespon dan bertanggung jawab atas } \\
\text { keluhan setiap anggota? }\end{array}$ & 125 & 83,33 \\
\hline 6 & $\begin{array}{l}\text { Bagaimana tingkat kedisiplinan, kesopanan, dan keramahan pelayanan } \\
\text { yang diberikan oleh karyawan koperasi? }\end{array}$ & 122 & 81,33 \\
\hline 7 & $\begin{array}{l}\text { Apakah produk yang dikeluarkan oleh koperasi di Toserba sudah tepat } \\
\text { dan aman untuk kebutuhan anggota? }\end{array}$ & 121 & 80,67 \\
\hline 8 & $\begin{array}{l}\text { Bagaimana kenyamanan yang diciptakan oleh pihak koperasi, ketika } \\
\text { sedang memberikan pelayanan kepada setiap anggota? }\end{array}$ & 122 & 81,33 \\
\hline 9 & $\begin{array}{l}\text { Bagaimana kelengkapan sarana dan prasarana yang dimiliki oleh } \\
\text { koperasi dalam melayani setiap anggota? }\end{array}$ & 125 & 83,33 \\
\hline 10 & $\begin{array}{l}\text { Bagaimana kemudahan akses (tempat, lokasi, sarana pelayanan) } \\
\text { produk yang dimiliki koperasi? }\end{array}$ & 122 & 81,33 \\
\hline
\end{tabular}

Berdasarkan tabel skor pelayanan koperasi pegawai jika diurutkan dari skor terendah sampai skor tertinggi, dapat dilihat diatas bahwa skor yang terendah merupakan pertanyaan no 7 yaitu tentang ketepatan dan keamanan produk yang dikeluarkan oleh koperasi di toserba untuk kebutuhan anggota dengan skor 121 atau 80,67\%, skor kedua pertanyaan no 6/8/dan 10 yaitu Bagaimana tingkat kedisiplinan, kesopanan, dan keramahan pelayanan yang diberikan oleh karyawan koperasi/ Bagaimana kenyamanan yang diciptakan oleh pihak koperasi, ketika sedang memberikan pelayanan kepada setiap anggota/ Bagaimana kemudahan akses (tempat,lokasi,sarana pelayanan) produk yang dimiliki koperasi mendapatkan skor yang sama yaitu 122 atau 81,33\%, skor ketiga pertanyaan no 4 yaitu Apakah setiap karyawan di Unit koperasi sudah menjalankan tugas dan melayani anggota dengan maksimal mendapat skor 123 atau 82,00\%, skor keempat pertanyan no 5/9 yaitu Apakah selama ini koperasi merespon dan bertanggung jawab atas keluhan setiap anggota / Bagaimana kelengkapan sarana dan prasarana yang dimiliki oleh koperasi dalam melayani setiap anggota mendapat skor yang sama yaitu 125 atau $83,33 \%$, skor kelima pertanyaan no 3 yaitu Bagaimana ketepatan dan kepastian waktu yang diberikan koperasi, ketika memberikan pelayanan dalam proses pencairan dana simpan pinjam, apakah sesuai dengan kurun waktu yang telah ditentukan mendapat skor 126 atau 84,00\%, skor keenam pertanyaan no 2 yaitu Apakah sistem pembayaran yang berlaku di pujasera koperasi, sudah tepat dan jelas untuk anggota mendapat skor 128 atau 85,33\%, skor ketujuh pertanyaan no 1 yaitu Apakah prosedur pelayanan simpan pinjam yang dilakukan oleh koperasi kepada anggota Mudah dilaksanakan, Mudah dipahami, dan Tidak berbelit-belit mendapat skor 137 atau $91,33 \%$. 
Tabel 10. Gambaran Persepsi Kesejahteraan

\begin{tabular}{|c|l|c|c|}
\hline NO & \multicolumn{1}{|c|}{ Kesejahteraan Pegawai Negeri Sipil } & \multicolumn{1}{|c|}{ Skor } & \multicolumn{1}{|c|}{} \\
\hline 1 & $\begin{array}{l}\text { Apakah produk simpan-pinjam koperasi sudah memenuhi kebutuhan } \\
\text { pegawai? }\end{array}$ & 132 & 88,00 \\
\hline 2 & $\begin{array}{l}\text { Apakah barang-barang yang tersedia di koperasi sesuai dengan } \\
\text { kebutuhan para pegawai? }\end{array}$ & 113 & 75,33 \\
\hline 3 & $\begin{array}{l}\text { Bagaimana rasa dan menu makanan yang diberikan pujasera } \\
\text { koperasi sesuai dengan kebutuhan pegawai? }\end{array}$ & 118 & 78,67 \\
\hline 4 & $\begin{array}{l}\text { Apakah dengan keberadaan koperasi dapat meningkatkan ekonomi } \\
\text { pegawai dengan cara menggunakan pembelian barang dan simpan } \\
\text { pinjam? }\end{array}$ & 119 & 79,33 \\
\hline 5 & $\begin{array}{l}\text { Sudahkah koperasi membangun potensi pegawai dalam mencapai } \\
\text { kesejahteraannya? }\end{array}$ & 101 & 67,33 \\
\hline
\end{tabular}

Berdasarkan tabel skor kesejahteran Pegawai Negeri Sipil Sekjen DPR-RI pada Wisma Griya Sabha jika diurutkan dari skor terendah sampai skor tertinggi dapat dilihat diatas, bahwa skor terendah merupakan pertanyaan no 5 yaitu Sudahkah koperasi membangun potensi pegawai dalam mencapai kesejahteraannya mendapat skor 101 atau 67,33\%, skor kedua yaitu pertanyaan no 2 yaitu Apakah barang-barang yang tersedia di koperasi sesuai dengan kebutuhan para pegawai mendapat skor 113 atau $75,33 \%$, skor ketiga pertanyaan no 3 yaitu Bagaimana rasa dan menu makanan yang diberikan pujasera koperasi sesuai dengan kebutuhan pegawai mendapat skor 118 atau 78,67\%, skor keempat pertanyan no 4 yaitu Apakah dengan keberadaan koperasi dapat meningkatkan ekonomi pegawai dengan cara menggunakan pembelian barang dan simpan pinjam mendapat skor 119 atau 79,33\%, dan skor kelima yang merupakan skor tertinggi pertanyaan no 1 yaitu Apakah produk simpan-pinjam koperasi sudah memenuhi kebutuhan pegawai mendapat skor 132 atau 88,00.

Gambar 2 : Kurva Pelayanan

Pelayanan

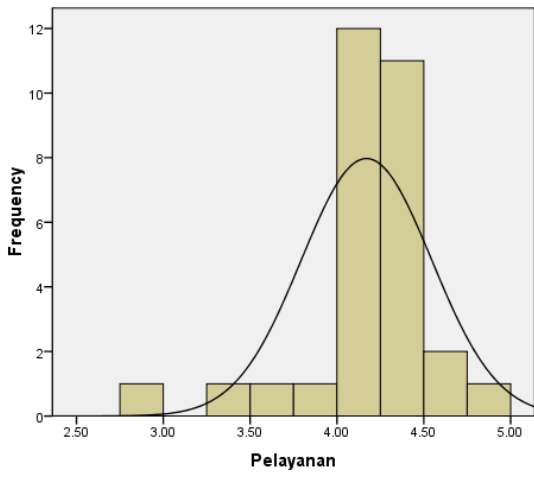

Mean $=4.17$
Std. Dev. $=0.375$
$N=30$

Berdasarkan kurva diatas dapat disimpulkan bahwa nilai kumulativ tertinggi adalah 43,3 yang menerangkan bahwa tingkat pelayanan koperasi pegawai sudah cukup tinggi.

Gambar 3 :Kurva Kesejahteraan

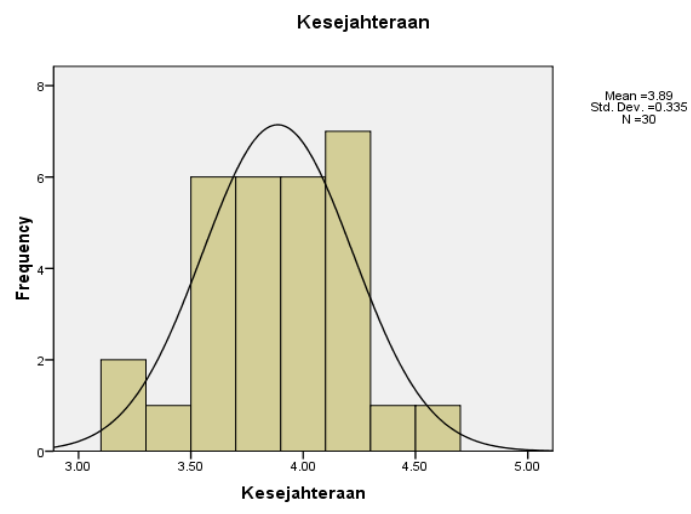

Martina Safitri ${ }^{1}$, Amelia $^{2}$, (Pengaruh Pelayanan Koperasi Setjen DPR-RI Terhadap Kesejahteraan...) 
Berdasarkan kurva diatas dapat disimpulkan bahwa nilai kumulativ tertinggi adalah 4,60 yang menerangkan bahwa tingkat kesejahteraan pegawai negeri sipil sekjen DPR-RI pada Wisma Griya Sabha belum cukup tinggi.

\section{Analisis Kuantitatif}

Tabel 11. Corelation

\begin{tabular}{|lr|r|r|}
\hline & & Pelayanan & Kesejahteraan \\
\hline Pelayanan & Pearson Correlation & 1 & .197 \\
& Sig. (2-tailed) & & .297 \\
& $\mathrm{~N}$ & 30 & 30 \\
\hline Kesejahteraan & Pearson Correlation & .197 & 1 \\
& Sig. (2-tailed) & .297 & \\
& $\mathrm{~N}$ & 30 & 30 \\
\hline
\end{tabular}

Korelasi Pearson (Pearson Correlation) $\quad=0,197$

Nilai 0,197 merupakan nilai $r$ hitung. Angka ini menunjukkan korelasi atau hubungan positif antara pelayanan koperasi pegawai dan kesejahteran Pegawai Negeri Sipil tinggi.

Sig (2-tailed) atau probalitas $=0,297$

Uji dilakukan 2 tailed ( 2 sisi) karena yang akan dicari adalah ada atau tidaknya hubungan dua variabel.

\section{Hipotesis :}

Ho : Tidak ada hubungan (korelasi) antara dua variabel

Hi : Ada hubungan (korelasi) antara dua variabel

\section{Dasar pengambilan keputusan :}

Jika probabilitasnya $>0,01$ maka Ho diterima

Jika probabilitasnya $<0,01$ maka Ho ditolak

Oleh karena signifikannya $<0,001$ maka Ho ditolak, berarti ada hubungan antara variabel X dan Y

$$
\mathrm{N} \text { atau jumlah yang dianalisis }=30
$$

Tabel 12. Model Summary

\begin{tabular}{|l|r|r|r|r|}
\hline Model & R & R Square & \multicolumn{1}{|c|}{$\begin{array}{c}\text { Adjusted R } \\
\text { Square }\end{array}$} & $\begin{array}{c}\text { Std. Error of } \\
\text { the Estimate }\end{array}$ \\
\hline 1 & $.197^{\mathrm{a}}$ & .039 & .004 & .33426 \\
\hline
\end{tabular}

a. Predictors: (Constant), Pelayanan

$\mathrm{R}$ disebut juga dengan koefisien korelasi. Dapat di baca bahwa nilai koefisien korelasi antara variabel pelayanan koperasi pegawai (X) terhadap kesejahteraan Pegawai Negeri Sipil Sekjen DPR-RI (Y) adalah 0,197 ( pada tabel ini tidak dituliskan nilai korelasi tersebut bernilai positif atau negatif).

$\mathrm{R}$ Square disebut koefisien determinasi. Dari tabel dapat dibaca bahwa nilai $\mathrm{R}$ square $\left(\mathrm{R}^{2}\right)$ adalah 0,039 .

Adjusted $\mathrm{R}$ square merupakan nilai $\mathrm{R}^{2}$ yang disesuaikan sehingga gambarannya lebih mendekati mutu penjajakan model dalam populasi. 
Tabel 13. Anova

\begin{tabular}{|r|r|r|r|r|r|}
\hline Model & \multicolumn{1}{|c|}{$\begin{array}{c}\text { Sum of } \\
\text { Squares }\end{array}$} & df & Mean Square & F & Sig. \\
\hline 1 Regression & .126 & 1 & .126 & 1.130 & $.000^{\mathrm{a}}$ \\
Residual & 3.128 & 28 & .112 & & \\
Total & 3.255 & 29 & & & \\
\hline
\end{tabular}

a. Predictors: (Constant), Pelayanan

b. Dependent Variable: Kesejahteraan

Tabel ini menampilkan Fhitung. Uji F berguna untuk menentukkan apakah model penaksiran yang digunakkan tepat atau tidak.

Model persamaan yang digunakkan adalah model linear $\overrightarrow{\mathbf{Y}}=\mathbf{a}+\mathbf{b X}$

Untuk menguji apakah model linear $\overrightarrow{\mathbf{Y}}=\mathbf{a}+\mathbf{b X}$ tersebut sudah tepat atau belum,

Cara untuk menentukkan ketepatan model diatas, yaitu dengan membandingkan probabilitas (pada tabel anova tertulis Sig)

Dengan taraf nyatanya $(0,05$ atau 0,01$)$.

Jika probabilitasnya $>0,05$ maka model ditolak

Jika probabilitasnya $<0,05$ maka model diterima

Dapat dilihat probabilitasnya (Sig) adalah $0,000<$ berarti model diterima atau dapat disimpulkan bahwa bentuk persamaan linear $\overrightarrow{\mathbf{Y}}=\mathbf{a}+\mathbf{b X}$ sudah tepat.

Tabel 14. Coefisient

\begin{tabular}{|c|c|c|c|c|c|}
\hline \multirow[b]{2}{*}{ Model } & \multicolumn{2}{|c|}{ Unstandardized Coefficients } & \multirow{2}{*}{$\begin{array}{r}\text { Standardized } \\
\text { Coefficients }\end{array}$} & \multirow[b]{2}{*}{$\mathrm{t}$} & \multirow[b]{2}{*}{ Sig. } \\
\hline & $\mathrm{B}$ & Std. Error & & & \\
\hline 1 (Constant) & 3.153 & .693 & & 4.554 & .000 \\
\hline Pelayanan & .176 & .165 & .197 & 1.063 & .297 \\
\hline
\end{tabular}

a. Dependent Variable: Kesejahteraan

Kolom Unstandartized Coefocients

- Constant (Konstanta) $\quad=3,153$

- Pelayanan =0,176

Dari sini di dapat persamaan regresi $\hat{Y}=\mathbf{3 , 1 5 3}+\mathbf{0 , 1 7 6}$

\section{Kolom t}

Kolom t berguna untuk menguji signifikan koefisien regresi (b), yaitu apakah variabel independent (X) berhubungan atau tidak.

Hipotesis :

Ho = pelayanan koperasi pegawai tidak berpengaruh terhadap kesejahteraan PNS Sekjen DPR-RI

$\mathrm{Ha}=$ pelayanan koperasi pegawai berpengaruh terhadap kesejahteraan PNS Sekjen DPR-RI :

Setiap kenaikkan 1 skor variabel pelayanan koperasi pegawai (X) dapat meningkatkan 0,176

Skor variabel kesejahteraan PNS Sekjen DPR-RI.

Pengambilan keputusan juga dapat dilakukan dengan melihat probabilitasnya dimana nilainya 0,000 lebih kecil dari 0,05 . 


\section{Interpretasi}

Berdasarkan hasil penelitian dapat disimpulkan bahwa hipotesis nol ditolak dan hipotesis alternatif diterima, hal ini menunjukkan bahwa terdapat hubungan positif dan dignifikan antara pelayanan koperasi pegawai terhadap kesejahteraan Pegawai Negeri Sipil Sekretariat Jenderal DPR-RI pada Wisma Griya Sabha.

Hal ini cukup berdasar karena kesejahteraan Pegawai Negeri Sipil Sekretariat Jenderal DPR-RI pada Wisma Griya Sabha dapat dipengaruhi oleh banyak faktor. Dalam penelitian ini penulis mengambil fokus bahwa benarkah faktor pelayanan koperasi pegawai berhubungan dengan kesejahteraan Pegawai Negeri Sipil Sekretariat Jenderal DPR-RI pada Wisma Griya Sabha. Setelah diadakan penelitian ternyata kedua variabel tersebut berhubungan positif dan signifikan.

Dengan demikian semakin baik pelayanan koperasi pegawai maka akan semakin baik meningkat pula kesejahteraan Pegawai Negeri Sipil Sekretariat Jenderal DPR-RI pada Wisma Griya Sabha.

\section{Pembahasan Hasil Penelitian}

Setelah melakukan penelitian dari bulan Mei di Wisma Griya Sabha Kopo Cisarua Bogor, yang melibatkan 30 orang pegawai negeri sipil, maka penulis mendapatkan hasil dari penelitian ini bahwa adanya hubungan antara pelayanan koperasi pegawai terhadap kesejahteraan Pegawai Negeri Sipil Sekretariat Jenderal DPR-RI pada Wisma Griya Sabha.

\section{KESIMPULAN}

Berdasarkan hasil pembahasan yang telah dikemukakan pada bab sebelumnya yaitu mengenai Pelayanan Koperasi Pegawai Sekretariat Jenderal DPR-RI Terhadap Pegawai Negeri Sipil Sekretariat Jenderal DPR-RI pada Wisma Griya Sabha, maka dapat ditarik kesimpulan sebagai berikut :

a. Koperasi adalah suatu lembaga yang dirancang untuk memberikan pelayanan bagi anggotanya yang sekaligus merupakan pemiliknya. Dalam koperasi, anggota sebagai pemilik dan pelanggan mempunyai posisi kekuasaan yang tertinggi, mereka mendirikan dan mengadakan perusahaan koperasi untuk meningkatkan taraf hidup dan kesejahteraannya. Maka dalam hal ini, kualitas pelayanan hendaknya dilihat dari sudut pandang anggota, anggotalah yang menentukkan nilai kualitas. Tercapainya kepuasan anggota dapat bermanfaat bagi terciptanya hubungan yang harmonis antara perusahaan koperasi dan anggota. Memberikan dasar yang baik untuk transaksi yang berulang, terciptanya loyalitas dan membentuk suatu rekomendasi dari mulut ke mulut. Dan untuk memelihara kesetiaan maka pelayanan koperasi hendaknya menggunakan program-program yang memberikan nilai tambah pada perusahaan koperasi dan produknya dimata anggota. Dengan cara membangun hubungan baik dalam jangka panjang kepada anggota, dan membangun komunikasi yang baik kepada setiap anggota.

Pada dasarnya pelayanan koperasi pegawai sekretariat jendral DPR-RIdapat dikatakan cukup baik dengan nilai persentase sebesar 43,3\%. Pelayanan koperasi dikatakan cukup karena belum sepenuhnya dari kegiatan dan produk koperasi dilakukan dengan sempurna oleh karyawan koperasi, masih adanya karyawan ataupun produk koperasi pegawai sekretariat jendral DPR-RI yang belum memaksimalkan kinerjanya.

b. Kesejahteraan karyawan yaitu seseorang dikatakan sejahtera apabila semua kebutuhan sosialnya menunjukkan dan mengarah kepada kondisi yang lebih baik daripada sebelumnya, Pegawai Negeri Sipil sekjen DPR-RI bekerja sama dengan Koperasi Pegawai Sekretariat Jenderal DPR-RI bermaksud untuk dapat mensejahterakan taraf hidupnya, dimana didalam koperasi seseorang mendapatkan timbal balik yang memudahkan mereka untuk mengarah kepada kehidupan yang lebih baik. Pada penelitian ini kesejahteraan pegawai sekretariat jenderal DPR-RI mendapatkan persentase sebesar 4,60\% yang artinya lebih besar dibandingkan dengan tingkat pelayanan dari Koperasi pegawai sekretariat jenderal DPR-RI, dan ini menunjukkan bahwa hampir semua Pegawai Negeri Sipil DPR-RI pada Wisma Griya Sabha mempunyai respon yang cukup baik terhadap keberadaan Koperasi pegawai sekretariat jenderal DPR-RI.

c. Berdasarkan analisis regresi dan korelasi maka dapat diketahui bahwa ada hubungan yang positif antara Pelayanan Koperasi Pegawai Sekretariat Jenderal DPRI-RI Terhadap Kesejahteraan Karyawan Pegawai Negeri Sipil Sekretariat Jenderal DPR-RI pada Wisma Griya Sabha, dengan 
nilai korelasi sebesar 0,197 artinya jika hubungan Pelayanan Koperasi Pegawai Sekretariat Jenderal DPRI-RI (X) tinggi maka Kesejahteraan Karyawan Pegawai Negeri Sipil Sekretariat Jenderal DPR-RI pada Wisma Griya Sabha (Y) akan baik.

d. Pelayanan Koperasi Pegawai Sekretariat Jenderal DPRI-RI sangat berpengaruh dalam perkembangan kesejahteraan pegawai.

\section{Saran - saran}

Setelah mengadakan penelitian baik melalui observasi langsung, wawancara atau penggunaan kuesioner, maka peneliti ingin memberikan saran kepada Koperasi Pegawai Sekretariat Jenderal DPRRI seperti berikut :

a. Pemeliharaan

Sistem simpan pinjam supaya dirawat dan dipelihara dengan baik, sehingga dapat terjaga daya olahnya. Pemeliharaan dan perawatan supaya dilakukan secara terus menerus, sehingga jika terjadi kesalahan yang berhubungan dengan sistem dapat diketahui dengan cepat. Selain itu juga diadakan evaluasi terhadap sistem secara berkala. Dari hasil evaluasi ini nantinya akan diketahui apakah sistem tersebut masih memenuhi kebutuhan organisasi atau tidak dan sudah perlu atau belum untuk diambil langkah-langkah penyempurnaan dan perbaikan terhadap sistem.

b. Disiplin para karyawan atau pegawai perlu ditingkatkan lagi terutama dalam lingkungan kerja.

c. Setiap pegawai hendaknya memahami peraturan-peraturan yang ada.

d. Selalu menerima dan menanggapi semua keluhan yang dikeluarkan oleh anggota.

\section{DAFTAR PUSTAKA}

Hanel, 1989, Pokok-pokok Pikiran Mengenai Organisasi Koperasi dan Kebijak-sanaan Pembangunan di Negara Berkembang, UNPAD, Bandung.

Hasibuan,Malayu. 2000Manajemen Sumber Daya Manusia. Edisi Revisi.Jakarta: PT Bumi Aksara

Siagian,Sondang P.(1994), Filsafat Administrasi, Jakarta : CV Haji Mas Agung

Soedjadi, FX. (1989). Organisasi dan Metode, Penunjang Berhasilnya Manajemen. Jakarta: Haji Masagung

Susilo Martoyo, ( 1992 ), Manajemen Sumber Daya Manusia, Edisi ke 2, ( 1992), BPFE UGM, Yogyakarta.

Yuyun, Wirasasmita. 1996. Fungsi Obyektif Koperasi. Ikopin, Bandung. 